\title{
Review
}

\author{
Journal of Innate \\ Immunity
}

\section{Vasopressin and Its Immune Effects in Septic Shock}

\author{
James A. Russell Keith R. Walley \\ Heart and Lung Institute, St. Paul's Hospital, University of British Columbia, Vancouver, B.C., Canada
}

\author{
Key Words \\ Vasopressin $\cdot$ Norepinephrine $\cdot$ Septic shock $\cdot$ Immunity • \\ Vasopressin receptors
}

\begin{abstract}
Vasopressin is a stress hormone. However, vasopressin levels are inappropriately low in septic shock. Vasopressin stimulates AVPR1a, AVPR1b, AVPR2 and purinergic receptors. Vasopressin increases blood pressure by occupying AVPR1a receptors on vascular smooth muscle. An increase in ventricular afterload due to vasopressor administration limits ventricular systolic ejection, an effect that becomes increasingly important as systolic contractility is decreased. Stimulation of AVPR1a receptors may also decrease edemagenesis. Stimulation of AVPR1b by vasopressin releases ACTH and cortisol. AVPR2 stimulation increases retention of water by increasing cyclic AMP. Yet, vasopressin infusion may increase urine output, creatinine clearance and improve renal function in septic shock. Vasopressin has many effects on immune function such as altering cytokines, neuroimmunity, prostaglandins, humoral immunity and immune cells. For example, vasopressin decreases sepsis-induced pulmonary inflammation, could have renal anti-inflammatory effects and may decrease prostaglandin levels in a dose-dependent manner. Vasopressin may also modulate responses to stress by expression and release from immune cells. Interestingly, there are vasopressin receptors on immune cells. Many small
\end{abstract}

clinical studies of vasopressin infusion in septic shock have shown that vasopressin infusion increases blood pressure, decreases requirements for norepinephrine and improves renal function. However, vasopressin could decrease coronary, cerebral and mesenteric perfusion. A multicenter trial of vasopressin versus norepinephrine in septic shock found no overall difference in mortality. Vasopressin may decrease mortality in patients with less severe septic shock. Vasopressin plus corticosteroid treatment may decrease mortality compared to corticosteroids plus norepinephrine. Potential mechanisms are that vasopressin plus corticosteroids beneficially alter immunity in septic shock.

Copyright $\odot 2010$ S. Karger AG, Basel

\section{Introduction}

Vasopressin is a critical stress response hormone. Vasopressin levels increase rapidly in septic shock, but then decrease to inappropriately low levels for the degree of hypotension. Low-dose vasopressin infusion increases vasopressin levels in septic shock, decreases dose requirements for infused norepinephrine and often improves renal function.

Vasopressin is an evolutionarily ancient central nervous system-derived signaling peptide [1]. It plays a lead role in volume homeostasis and blood pressure regulation in stress states. Therefore, it is not surprising that it

\section{KARGER \\ Fax +4161306 1234 \\ E-Mail karger@karger.ch}

www.karger.com
(C) 2010 S. Karger AG, Basel

$1662-811 X / 10 / 0025-0446 \$ 26.00 / 0$

Accessible online at:

www.karger.com/jin
Dr. James A. Russell

Critical Care Medicine, St. Paul's Hospital

1081 Burrard Street

Vancouver, BC V6Z 1Y6 (Canada)

Tel. +1 604806 8272, Fax +1 604806 8599, E-Mail Jim.Russell@ hli.ubc.ca 
is of central importance in shock states and plays multiple roles via a variety of receptors. The mechanism of action of vasopressin in shock-related physiologic states has been understood at a rudimentary level for many years, but recently understanding of vasopressin's many roles has expanded substantially.

It has been long understood that vasopressin is produced in magnocellular neurons in the hypothalamus, stored in axonal terminals of these cells located in the posterior pituitary gland, and released in response to (1) hyperosmolality of extracellular fluid and (2) hypotension. Classically, vasopressin binding to V1 receptors (also known as V1a receptors, AVPRla) increases blood pressure by increasing vascular tone and vasopressin mediates its antidiuretic hormone activity by binding to V2 receptors (AVPR2) in the kidney. Vasopressin also binds $\mathrm{V} 3$ receptors (also known as V1b receptors, AVPR1b) in the central nervous system, resulting in incompletely delineated central nervous system effects. Conventional understanding is that arterial hypotension associated with shock states is the strongest stimulus for vasopressin release from the posterior pituitary and for a resulting increase in blood vasopressin concentrations. However, recent findings have expanded our understanding. In addition to increased understanding of its classical physiologic effects, vasopressin has recently been found to have important effects in modulating the inflammatory response.

\section{Gene Structure, Synthesis and Release of Vasopressin}

The vasopressin gene is conserved across mammalian species (as arginine vasopressin except for pig which has lysine vasopressin). The vasopressin gene and oxytocin gene are linked on the short arm of chromosome 20. The precursor of vasopressin is preprovasopressin which has vasopressin, neurophysin II and copeptin linked together. Neurophysin II plays a role in the packaging of vasopressin in secretory granules. Vasopressin is a nonapeptide.

Vasopressin is released into both the systemic circulation and the portal circulation to the anterior pituitary gland from the posterior pituitary gland. Vasopressin, like many hormones, is synthesized as a prohormone and is then cleaved to form the mature active hormone. Interactions of the synthesis, release and metabolism control the serum levels of vasopressin. Preprovasopressin is synthesized in neurohypophyseal neurons (magnocellular neurons) of hypothalamic paraventricular and supraoptic nuclei. Provasopressin is packaged in neurosecretory granules and transported along the suprahypophyseal tract to the posterior pituitary. Subsequently, there is conversion of provasopressin by subtilisin-like proprotein convertase (SPC3) to vasopressin. LNPEP (vasopressinases) metabolizes vasopressin and vasopressin has a short half-life of 6-10 min. Hypotension and hyperosmolality stimulate immediate release of stored vasopressin and trigger synthesis of new vasopressin. Hypotension is a powerful stimulus for new synthesis of vasopressin; indeed, vasopressin synthesis increases within about 10 min after onset of hypotension [2]. Thus, vasopressin stores are ample and available for instantaneous release from the posterior pituitary in response to hypotension. The relative importance of hypotension as a stimulus to vasopressin release is illustrated by studies showing that if an animal is challenged with conflicting signals to vasopressin release, such as hypotension (which should increase vasopressin levels to restore blood pressure) and hyponatremia (which should decrease vasopressin levels to increase serum sodium), vasopressin levels will increase. Cytokines such as IL-1 $\beta$ also increase vasopressin expression [3] and could be an important additional modulator of vasopressin levels in septic shock.

\section{Circulating Vasopressin Concentrations}

In health, vasopressin concentrations in the blood are low, in the range of $1-4 \mathrm{pg} / \mathrm{ml}$. When faced with dehydration and corresponding hypertonicity of extracellular fluid, vasopressin is released and blood concentrations rise to $10-20 \mathrm{pg} / \mathrm{ml}$. Shock and hypotension initially induce greater release of posterior pituitary vasopressin stores resulting in increased blood vasopressin concentrations [4] of up to $100-500 \mathrm{pg} / \mathrm{ml}$. Vasopressin levels decline rapidly after the initial release of vasopressin (at least in part because of depletion of stored vasopressin [5]) to levels that are inappropriately low compared to similarly hypotensive patients who had cardiogenic shock $[6-8]$. Landry et al. $[6,7]$ first discovered that vasopressin levels are inappropriately low in septic shock. Others found [9] in patients in emergency rooms that vasopressin levels were lower in those who went on to septic shock (3.6 $\mathrm{pg} / \mathrm{ml})$ compared to those who had sepsis $(10.6 \mathrm{pg} /$ $\mathrm{ml})$ and severe sepsis $(21.8 \mathrm{pg} / \mathrm{ml})$. Vasopressin levels remain extremely low for up to 7 days after onset of septic shock [10]. The vasopressin axis represents one example of several hormone systems that are rapidly activated (to 
increase serum levels) in septic shock and then so rapidly exhausted (such that serum levels decrease).

Increased expression and activity of iNOS, and consequently nitric oxide, contributes to the early increase in vasopressin release in septic shock $[11,12]$. In contrast, heme oxygenase activation attenuates the early increase in vasopressin levels that occurs in septic shock [13].

A number of mechanisms may contribute to the subsequent decreased and sustained low vasopressin levels during septic shock. The baroreceptor reflex, which leads to increased vasopressin release in normal physiologic settings, is downregulated in sepsis [14]. In addition, NO released by inflammation-upregulated iNOS downregulates hypothalamic activation and vasopression production [15]. The type of resuscitation fluid may alter blood vasopressin concentrations [16]. Isotonic solutions did not increase vasopressin levels, whereas hypertonic solutions increased vasopressin levels and resulted in a greater increase in blood pressure [16], an effect mediated by AVPR1a (V1) receptors. Further interaction is suggested by the ability of AVPR1a receptor antagonists to block the hypertensive effect of hypertonic saline [17]. Sustained release of vasopressin depends to some extent on desensitization-resistant purinergic receptors type $\mathrm{P} 2 \mathrm{X}$, whose recruitment is partially dependent on $\alpha 1$-adrenoreceptors [18] which are downregulated during septic and other forms of shock.

Since vasopressin is rapidly degraded by circulating vasopressinases (half-life of 6-10 min), ongoing production and release is required to sustain levels. This also means that vasopressin blood concentrations may not be good measures of vasopressin production and release. Copeptin is a 39 amino acid glycopeptide which is located at the $\mathrm{C}$ terminal of provasopressin. Copepetin is easier to measure than vasopressin because copeptin is stable in serum. Therefore, some authors have suggested that copeptin could be used as a surrogate for measurement of vasopressin.

Serum copeptin levels are much higher in human sepsis and septic shock (critically ill, no sepsis $27 \mathrm{pM}$; sepsis $50 \mathrm{pM}$; severe sepsis $74 \mathrm{pM}$; septic shock $171 \mathrm{pM}$ ) than normal volunteers (4 pM) [19]. Similar to prior studies of vasopressin levels, patients after cardiovascular surgery usually have higher vasopressin [1] and copeptin [11, 12] levels than patients with septic shock. Copeptin levels are related to subsequent survival: copeptin was higher in nonsurvivors (vs. survivors) of adult septic shock (171 vs. $87 \mathrm{pM}$ [19]; 70 vs. $24 \mathrm{pM}$ [20]) and of pediatric septic shock [21].

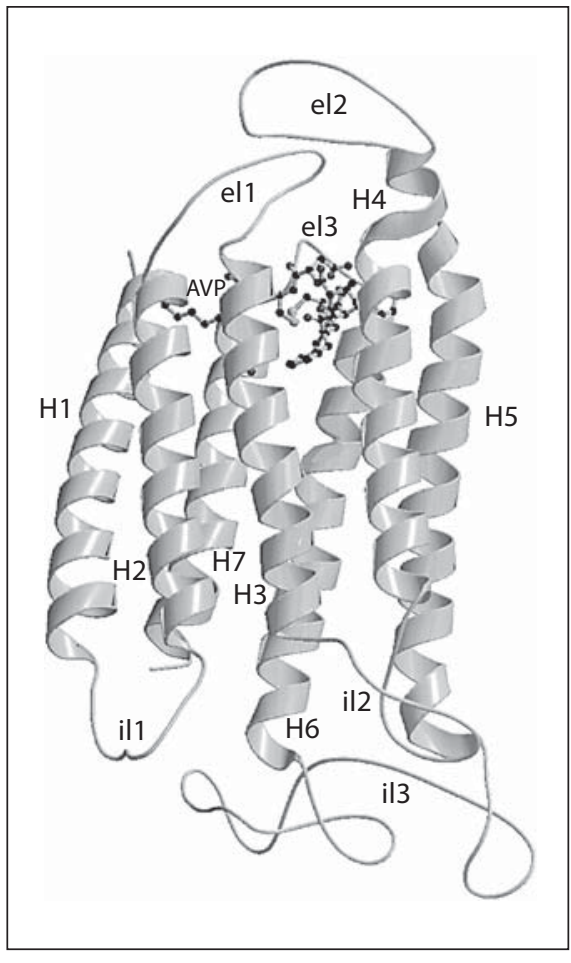

Fig. 1. Vasopressin (line and beads) occupies the AVPRla receptor. The ribbons show the receptor and the beads and sticks repesent vasopressin occupying the receptor.

\section{Vasopressin Receptors}

Vasopressin stimulates a family of receptors: AVPR1a (also known as V1a), AVPR1b (also known as V1b) and AVPR2 (also known as V2). AVPR1a, a G protein-coupled receptor, is responsible for vasoconstriction associated with vasopressin and is expressed on vascular smooth muscle, hepatocytes and platelets (fig. 1). G proteins stimulate a phosphatidylinositol-calcium signaling pathway causing smooth muscle contraction [22-24]. Genetic variants of AVPRla have been associated with essential hypertension [23], autism [25] and generosity [26].

There is an important interaction of vasopressin and the adrenal axis in response to stresses such as hypotension $[27,28]$ that is linked by the AVPR1b receptor (fig. 2). AVPR1b (or AVPR3) is expressed in the anterior pituitary gland and hippocampus. Stimulation of AVPR1b by vasopressin releases ACTH because vasopressin flows from the posterior pituitary through pituitary portal capillaries to bind to the AVPR1b on corticotrophic cells of the anterior pituitary. Thus, vasopressin interacts with the corticosteroid axis in response to stresses such as hypo- 
Fig. 2. Vasopressin occupies the AVPR1b receptor. Schematic representation of the three-dimensional model of the AVPR $1 b$ receptor. Two different orientations are shown. The 191 and the 364 residues are highlighted (orange halos). The former is in close proximity to the Asp185 and Cys186 residues (green halos) that are known to be in close contact with vasopressin. From Cagliani et al. [115].

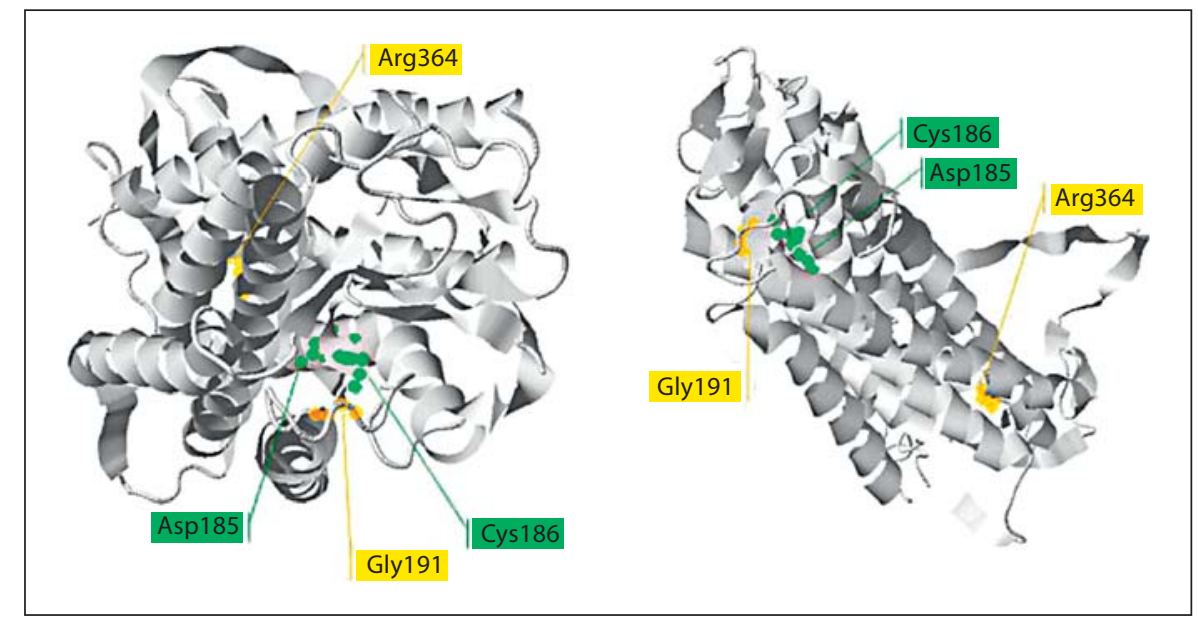

tension [27, 28]. Vasopressin and corticotrophin-releasing hormone $(\mathrm{CRH})$ stimulate different signaling systems and have synergistic effects on release of ACTH. The AVPR1b receptor is important in the acute response to stress. AVPR1b knockout mice have impaired acute stress response because of blunted ACTH response [29]. It is also important to note that vasopressin stimulation of corticotrophic cells is not downregulated in response to increased cortisol levels, whereas the corticotropin-releasing hormone (CRF)/ACTH response is.

AVPR2 is central to water balance regulation managed by vasopressin (fig. 3). AVPR2 is expressed in the renal collecting duct. AVPR2 stimulation increases retention of water (anti-diuretic activity) by increasing cyclic AMP which causes movement of aquaporin- 2 water channels from cytoplasm to the apical membrane of collecting duct cells. If there is vasopressin deficiency, aquaporin-2 channels internalize from the apical membrane to subapical vesicles so that there is no active water reabsorption. Vasopressin deficiency decreases synthesis of aquaporin-2, which also decreases water reabsorption.

Stimulation of the AVPR2 receptor increases release of von Willebrand factor (vWF), vWF multimers and risk of clotting. Hence, stimulation of AVPR2 is the mechanism of increased coagulation in response to ddAVP. Interestingly, vWF levels are increased in sepsis [30,31], but it is unknown whether vasopressin increases vWF and risk of thrombosis in septic shock. In the Vasopressin and Septic Shock Trial (VASST) [10], there was no difference between vasopressin and norepinephrine in the occurrence of thrombotic events such as myocardial infarction, stroke or mesenteric ischemia, although there was nu-

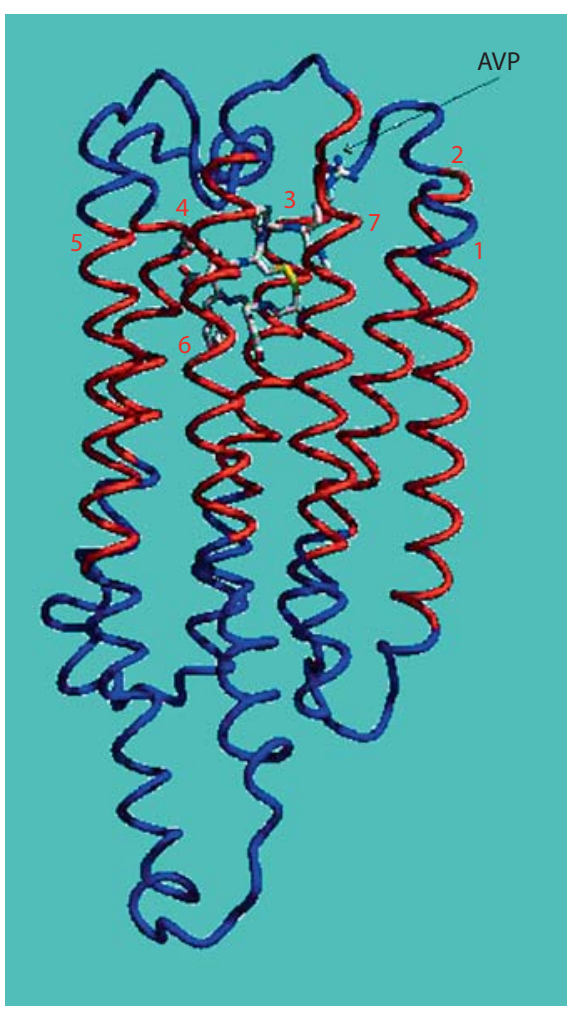

Fig. 3. Vasopressin (AVP) occupies the AVPR2 receptor. Threedimensional model of the human arginine vasopressin (AVP) receptor (V2), which is encoded by the AVPR2 gene, with the vasopressin docked into the putative active site. Side view from a direction parallel to the cell membrane surface. The transmembrane helices are shown in red, the intracellular and extracellular loops are shown in blue. The model is oriented such that the extracellular side is at the top. 
merically more digital ischemia associated with vasopressin than norepinephrine.

Sepsis may downregulate vasopressin receptors. Models of sepsis decrease expression of AVPRla, therefore limiting smooth muscle contraction and increase in blood pressure [32-34], AVPR2 [35] and AVPR3 receptors [36]. Downregulation of AVPR1a in lung, liver, kidney and heart is likely caused by increased TNF- $\alpha$, IL-1 $\beta$, IL- 6 and IFN- $\gamma[32,34]$. The magnitude of downregulation of AVPRla may be large because continuous infusion of lipopolysaccharide (LPS) decreased AVPRla expression by $43 \%$ in one study [33].

Models of sepsis also downregulate AVPR1b and AVPR2. LPS decreases mRNA levels of the AVPR1b receptor in the pituitary [36] and downregulates AVPR2 expression in rat renal medulla [35].

\section{Vasopressin and Its Effects on Vascular Tone}

It has been long recognized that vasopressin increases vascular tone and, therefore, blood pressure by binding to $\mathrm{V} 1$ receptors (also known as V1a receptors) on vascular smooth muscle. However, the action of vasopressin is more complicated, particularly in the setting of shock and sepsis [37]. Yang et al. show that in a model of hemorrhagic shock the superior mesenteric artery becomes hyporesponsive to conventional vasoconstrictors [38]. Vasopressin administration left-shifts concentration-response curves to norepinephrine and calcium, thus restoring vascular reactivity $[38,39]$. Vasopressin also acts to restore vascular tone in septic shock by inhibition of opened ATP-sensitive potassium ( $\left.\mathrm{K}_{\mathrm{ATP}}\right)$ channels, an effect which is enhanced by V1 receptor signaling via protein kinase C [40].

Vasopressin also increases venous vascular tone so that mean systemic filling pressure is increased by vasopressin administration [41]. This effect should increase venous return. However, cardiac output is generally unchanged or decreased, indicating that vasopressin has additional effects on cardiac function.

\section{Vasopressin and Effects on Cardiac Function}

One fairly uniform observation is that vasopressin infusion decreases the heart rate. In healthy subjects, the decrease in heart rate appears to be due to the baroreceptor reflex. In septic shock the baroreceptor reflex is downregulated [42], yet vasopressin infusion compared to nor- epinephrine still results in a decrease in heart rate and a decrease in catecholamine infusion rates $[10,43]$. In this setting, the bradycardic effect of vasopressin infusion may be partially due to sparing of catecholamine vasopressors.

An increase in ventricular afterload due to vasopressor administration limits ventricular systolic ejection, an effect that becomes increasingly important as systolic contractility is decreased. This may be important in some patients who have septic shock and depressed left ventricular contractility. Therefore, vasopressin infusion to increase arterial pressure in shock states has the potential to decrease stroke volume and cardiac output. Furthermore, vasopressin may increase coronary arterial vasoconstriction and therefore has the potential to decrease coronary blood flow and induce ischemia. Indeed, the more selective $\mathrm{V} 1$ receptor agonist, terlipressin, induced coronary vasoconstriction in an animal model which was associated with a decrease in contractile function [44]. In another animal model of cardiac ischemia, vasopressin infusion resulted in decreased vital organ blood flow, in particular to the heart [45]. This concern resulted in exclusion of patients with recent evidence of coronary insufficiency from the VASST trial [10]. Therefore, we have limited knowledge of the effect of vasopressin in the setting of coronary artery disease and myocardial ischemia.

In a myocardial ischemia-reperfusion model, vasopressin infusion resulted in a decrease in ejection fraction [46]. Since pressure afterload was similar to control values, there appeared to be an intrinsic decrease in myocardial contractility. This did not appear to be due to changes in V1 receptor density but oxytocin receptor expression was reduced by $40 \%$ in vasopressin-treated animals [46]. Seven-day mortality was increased in vasopressintreated animals compared to controls. Furthermore, in a fecal peritonitis model of septic shock, troponin I blood levels where increased in vasopressin-treated animals compared to controls [43]. Thus, vasopressin may have direct ventricular contractile effects in shock states and these effects may be mediated directly or indirectly (for example through coronary blood flow) by V1 and other receptors.

\section{The Effects of Vasopressin on Renal Function}

Vasopressin infusion increased urine output in several small clinical studies of septic and distributive shock $[47,48]$, may increase creatinine clearance [47-49], and 
results in improved outcome and renal function in those patients in the RIFLE risk category of renal dysfunction in the VASST trial [50]. In a septic shock model in pigs, increased vasopressin infusion resulted in less severe renal dysfunction and decreased renal tubular apoptosis [43].

The septic inflammatory response, modeled by cecal ligation and puncture, and subsequent signaling via NF$\kappa \mathrm{B}$ caused a time-dependent downregulation of renal V2 receptors which was postulated to contribute to acute kidney injury in sepsis [51]. Indeed, in a rat endotoxin model the V2 agonist desmopressin restored endotoxininduced decreases in sodium reabsorption, inner medulary osmolality and urine osmolality, while decreasing urine flow [52], suggesting that V2 receptor stimulation plays a beneficial role. In contrast, in an animal model of sepsis which resulted in impaired renal function in the presence of vasopressin, V2 receptors appeared to mediate impaired creatinine clearance [53]. Thus, V2 receptor agonist activity appears to be involved in renal dysfunction of sepsis but the beneficial versus adverse mechanisms are incompletely elucidated.

\section{The Effects of Vasopressin on Other Organ Dysfunction}

There is ongoing concern that low-dose vasopressin used to treat septic shock may reduce mesenteric blood flow $[54,55]$ as it does, for example when vasopressin is infused in high doses in the setting of variceal hemorrhage. A range of results are reported in animal models of sepsis and shock [55-58], but, overall, vasopressin effects appear to be relatively minimal and hepatosplanchnic microcirculatory flow may also be maintained [58, 59]. Indeed, vasopressin may have a beneficial effect on the gut microcirculation [60]. In a septic shock model in pigs, vasopressin infusion increased glucose oxidation, reduced blood lactate concentrations and decreased liver injury [43].

Similarly, there is a concern that vasopressin could decrease cerebral blood flow. In a porcine hemorrhagic shock model vasopressin infusion did not alter S100ß levels, suggesting that vasopressin did not result in increased cerebral damage [61]. Vasopressin appears to have additional effects in other organs. Skeletal muscle wasting contributes substantially to morbidity in septic shock and is contributed to by inhibition of muscle regeneration by TNF. Vasopressin counteracted the effects of TNF in myocyte cell cultures [62].

Vasopressin in Septic Shock

\section{The Effects of Vasopressin on Endothelial Permeability}

Shock states trigger an inflammatory response. For septic shock the main triggers are pathogen-derived molecules (pathogen-associated molecular patterns) such as Gram-negative endotoxins, Gram-positive cell wall products and viral nucleic acids. For hypovolemic shock, cardiogenic shock and obstructive shock, endogenous molecules (danger-associated molecular patterns) produced or released, such as heat shock proteins and S100A8/A9 [63], trigger very similar innate immune receptors and the subsequent inflammatory response.

A variety of inflammatory mediators result in increased endothelial permeability $[64,65]$. This results in permeability pulmonary edema which contributes to acute lung injury and the acute respiratory distress syndrome. Increased endothelial permeability also contributes to tissue edemagenesis in many organs. Tissue edema contributes to impaired tissue oxygen extraction and delayed restoration of organ function in shock patients. Recently, vasopressin has been found to play a significant role in tissue edemagenesis.

V1 receptors appear to decrease edemagenesis in a smoke inhalation, bacterial exposure acute lung injury model [66]. Terlipressin is a vasopressin analogue with greater V1 receptor specificity. Terlipressin compared to vasopressin in an ovine model of fulminant septic shock resulted in a reduction in positive fluid balance during the first $12 \mathrm{~h}$ of shock supporting the hypothesis that V1 receptor signaling limits edemagenesis of sepsis.

\section{Inflammatory and Immune Effects of Vasopressin}

Much more research is needed on the effects of vasopressin infusion on inflammation and immunity in septic shock. Two observations regarding the VASST randomized controlled trial of vasopressin versus norepinephrine in septic shock highlight a need to understand the immune effects of vasopressin infusion. First, the potentially beneficial effects of vasopressin in patients who had less severe septic shock found in the VASST became evident after about 10 days of vasopressin infusion (based on the observation that this is when the vasopressin and norepinephrine groups begin to separate on the KaplanMeier survival curves [10]). This is a time when effects of vasopressin on inflammation and immunity could explain the separation of rates of survival between groups. Second, the combination of vasopressin infusion and

J Innate Immun 2010;2:446-460 
Table 1. Inflammatory and immune effects of vasopressin

\begin{tabular}{|c|c|c|c|c|}
\hline $\begin{array}{l}\text { Inflammatory and } \\
\text { immune molecules, } \\
\text { cells and mechanisms }\end{array}$ & Author & Model or species & Effects of vasopressin (or analogues) & $\begin{array}{l}\text { Receptor(s) involved } \\
\text { as mechanism of } \\
\text { action of vasopressin } \\
\text { (or analogues) }\end{array}$ \\
\hline Cytokines & $\begin{array}{l}\text { Zhao et al., } \\
2004 \text { [67] }\end{array}$ & Rat astrocytes & $\begin{array}{l}\downarrow \text { TNF- } \alpha \text { mRNA and protein } \\
\downarrow \text { IL- } 1 \beta \text { mRNA and protein } \\
\text { Neuroprotection }\end{array}$ & AVPRla \\
\hline Neuroimmunity & $\begin{array}{l}\text { Banisadr et al., } \\
2003[71]\end{array}$ & Rat brain & $\begin{array}{l}\text { MCCP-1/CCL2 co-localized with AVPR1b } \\
\text { receptors in hypothalamus }\end{array}$ & AVPR1b \\
\hline Neuroimmunity & $\begin{array}{l}\text { Banisadr et al., } \\
2003[71]\end{array}$ & Rat brain & $\begin{array}{l}\text { SDF-1/CXCL12 co-localized with vasopressin- } \\
\text { expressing neurons in the supraoptic and para- } \\
\text { ventricular hypothalamic nuclei }\end{array}$ & \\
\hline Prostaglandins & $\begin{array}{l}\text { Fleischer-Berkovich } \\
\text { et al., } 2004 \text { [74] }\end{array}$ & Human dermal cells & $\begin{array}{l}\text { Low concentration of AVP } \downarrow \text { PGE2 } \\
\text { High concentration of AVP } \uparrow \text { PGE2 }\end{array}$ & \\
\hline $\begin{array}{l}\text { Macrophages, } \\
\text { lymphocytes }\end{array}$ & $\begin{array}{l}\text { Baker et al., } \\
2003 \text { [75] }\end{array}$ & $\begin{array}{l}\text { Human macrophages, } \\
\text { B and T lymphocytes }\end{array}$ & $\begin{array}{l}\text { AVP localized in human macrophages, } \mathrm{B} \text { and } \mathrm{T} \\
\text { lymphocytes }\end{array}$ & \\
\hline Plasma cells & $\begin{array}{l}\text { Jessop et al., } \\
1995[77]\end{array}$ & Rat spleen & $\begin{array}{l}\text { AVP localized in rat IgG-staining plasma cells of } \\
\text { spleen }\end{array}$ & \\
\hline Lymphocytes & $\begin{array}{l}\text { Wickramasinghe et al., } \\
1982[78]\end{array}$ & Human lymphocytes & $\begin{array}{l}\text { Binding of ddAVP and AVP to AVP receptors } \\
\text { on human lymphocytes }\end{array}$ & \\
\hline Lymphocytes & Ekman et al., 2001 [80] & Human lymphocytes & AVP localized in human lymphocytes & \\
\hline NK cells & $\begin{array}{l}\text { Yirmiya et al., } \\
1989[86]\end{array}$ & Rats & $\begin{array}{l}\text { AVP deficiency } \\
\uparrow \text { NK activity }\end{array}$ & \\
\hline
\end{tabular}

MIP-2 = Macrophage inflammatory protein 2; NK = natural killer.

corticosteroid treatment may have decreased mortality in the VASST. Of note, both vasopressin and corticosteroid treatment have important effects on inflammation and immunity.

There is a wealth of research on the inflammatory and immune effects of vasopressin, although little has been done in the field of sepsis and septic shock. Published studies focused on the effects of vasopressin (and which specific vasopressin receptors are needed) on cytokines, neuroimmunity (because vasopressin is a neurohormone), prostaglandins, humoral immunity and immune cells (table 1). These effects of vasopressin on immune function could modulate the global effects of vasopressin infusion in human septic shock and may be important in interpreting the results of studies such as the VASST.

There are few studies of the effects of vasopressin on cytokine expression. Astrocytes are the key immune response cells of the brain. Vasopressin decreased both 
mRNA and protein expression of TNF- $\alpha$ and IL-1 $\beta$ of astrocytes via AVPR1a (table 1), so vasopressin may be anti-inflammatory in the brain [67]. Vasopressin decreases sepsis-induced pulmonary inflammation through the V2 receptor [68]. Using an intraperitoneal endotoxin model of sepsis, Boyd et al. [68] found that a vasopressin infusion decreased NF- $\kappa \mathrm{B}$ activation and subsequent serum and pulmonary IL- 6 concentrations. This effect was attenuated by a specific $\mathrm{V} 2$ receptor antagonist, not by a specific V1 receptor antagonist. Conversely, the septic inflammatory response appears to downregulate V1 receptor expression via NF- $\kappa \mathrm{B}$ [32].

Vasopressin could have renal anti-inflammatory effects and thus decrease bacterial clearance in the lower urinary tract by binding to AVPR2. Thus, it could modulate the innate immune response to lower urinary tract infection [69]. Collecting duct cells are the important sites of bacterial adhesion and the inflammatory response and are also the sites of action of vasopressin on renal water absorption. Renal collecting duct cells that express TLR- 4 and TLR- 4 are important in the renal inflammatory response to common urinary tract infections such as Escherichia coli. Indeed, TLR-4 knockout mice do not effectively clear Gram-negative bacteria from the lower urinary tract [70]. Chassin et al. [69] used a model of pyelonephritis and found that ddAVP (a potent AVPR2 agonist) inhibited TLR-4, decreased the transcription factor $\mathrm{NF}-\kappa \mathrm{B}$ as well as downstream chemokines (including macrophage inflammatory protein 2, MIP-2) and cytokines (TNF- $\alpha$ ) in collecting ducts of rats in response to LPS. That is, dd AVP inhibited LPS-mediated cell activation. This effect required both phosphatase $2 \mathrm{~A}$ and the cystic fibrosis transmembrane conductance regulator chloride channel. ddAVP infusion in vivo in rats also decreased neutrophil recruitment and pro-inflammatory cytokine expression in renal collecting duct and these effects were associated with much increased bacterial burden in a model of urinary tract infection. These adverse effects of ddAVP (that is, inhibition of MIP-2 in response to LPS and increased bacterial burden) were completely reversed by the AVPR 2 antagonist SR121463B. Thus, the effects of vasopressin on cytokines and bacterial killing in the kidney could be anti-inflammatory through AVPR2.

Therefore, the renal effects of vasopressin could be beneficial (anti-inflammatory effects could decrease inflammation-induced renal injury) or detrimental (by increasing bacterial infection) depending on variables such as bacterial load, underlying immune status of the host as well as the timing and type of vasopressin agonist treat- ment (such as vasopressin, an AVPRla agonist or an AVPR2 agonist).

Vasopressin is an important neuro-immune hormone that has emerged as a regulator of immune function in a complex neuroendocrine-immune network. Some immune receptor systems such as MCCP-1/CCL2 and SDF1/CXCL12 co-localize with AVPR1b receptors (MCCP-1/ CCL2) and with vasopressin-expressing neurons (SDF-1/ CXCL12) in the hypothalamus [71]. This suggests an interaction of vasopressin with immune receptor systems of the brain. Interestingly, osmotic challenge modulates vasopressin levels and also modulates the expression of chemokines in the neurons of the magnocellular and paraventricular nuclei of the hypothalamus where vasopressin is synthesized [73].

Vasopressin may alter prostaglandin levels in a dosedependent manner, a relevant finding because of controversy regarding the optimal dose of vasopressin in septic shock. IL-1 $\beta$ increases PGE-2 synthesis and release by fibroblasts and this increase was diminished significantly by low concentrations of vasopressin [74]. Low concentrations of vasopressin also inhibited basal PGE-2 production. In contrast, higher concentrations of vasopressin increased the PGE-2 response to IL-1 $\beta$. Furthermore, higher concentrations of vasopressin alone increased PGE-2 of fibroblasts. These effects of vasopressin were reversed by co-administration of a vasopressin AVPR1a antagonist SR49059 and a vasopressin AVPR2 antagonist SR121463 [74].

Vasopressin may modulate responses to stress by virtue of expression and release from immune cells. It is expressed in the cells of the immune system and is released in response to inflammatory stimuli, suggesting a direct role for vasopressin in modulating immune response. Vasopressin is expressed in peripheral mononuclear cells including T cells, B cells and monocytes/macrophages [74]. Interestingly, it is co-localized with CRF in T cells, B cells and monocytes/macrophages [75]. Vasopressin is also found in human thymic epithelial cells [76] and in B cells of the spleen [77]. Furthermore, vasopressin of immune cells is released in response to chronic inflammation (adjuvant arthritis) [79]. Vasopressin modulates helper signaling by interaction with a novel receptor on splenic lymphocytes. Vasopressin also interacts with natural killer cells: vasopressin deficiency (in Brattleboro rats) increases natural killer cell activity.

There are vasopressin receptors on immune cells. ddAVP and AVP bind to AVP receptors on human lymphocytes [80, 81], on spleen lymphocytes [82] and on human mononuclear cells. 
Another indirect role for vasopressin in modulating immune response is suggested by findings that vasopressin of immune cells also interacts with the CRH/ACTH axis of immune cells to further modulate immune responses. For example, vasopressin potentiates CRH-induced ACTH release from peripheral blood monocytes [83].

Vasopressin alters acquired immunity. It modulates primary antibody production by potentiating production of IgM and by activating T cells [84]. Vasopressin appears to modulate humoral immune responses in that it (via AVPR1a) may be a negative regulator of B cell receptor signaling (based on studies of AVPRla knockout mice [85]). AVPR1a knockout mice have a shift of immunoglobulins from IgM (high)/IgD (high) to the more mature IgM (low)/IgD (high) expression in B cells (that is, vasopressin alters B cell development) and have greater splenic B cell proliferation. AVPRla knockout mice also show enhanced IgG2a and decreased IgG2b compared to normal mice.

Thus, there is a complex relationship between vasopressin, inflammation and immunity that could be part of the complex effects of vasopressin infusion in patients who have septic shock.

\section{VASST - A Randomized Controlled Trial of Vasopressin versus Norepinephrine in Septic Shock}

There have been many relatively small clinical studies of vasopressin infusion in septic shock that showed that vasopressin infusion increases blood pressure, decreases dose requirements for norepinephrine and often improves renal function. However, none of these studies were powered for mortality. The VASST was a randomized controlled trial of vasopressin versus norepinephrine in patients with septic shock [10]. The primary hypothesis was that vasopressin, compared to norepinephrine infusion, would decrease 28-day mortality from 60 to $50 \%$. An important secondary hypothesis was that the effects of vasopressin, compared to norepinephrine, would be more pronounced in patients with more severe septic shock. We therefore stratified patients into less and more severe septic shock.

Patients were randomized to vasopressin or norepinephrine infusion. Blinded vasopressin infusion was titrated from 0.01 to $0.03 \mathrm{U} / \mathrm{min}$ while blinded norepinephrine infusion was titrated from 5 to $15 \mu \mathrm{g} / \mathrm{min}$. Clinicians titrated open-label vasopressors to maintain mean arterial pressure of $65-75 \mathrm{~mm} \mathrm{Hg}$.
Patients enrolled in the VASST were severely ill (for example high APACHE II scores, high fraction with new organ dysfunction, high norepinephrine infusion rates). Mean arterial pressure was similar in the two treatment groups. Heart rate was significantly lower in the vasopressin than in the norepinephrine group (first 4 days). As in many previous human trials $[1,6,7,47,87-102]$, vasopressin infusion allowed rapid decrease of norepinephrine dose over the first four days. As expected, plasma vasopressin was extremely low at baseline (median 3.2 $\mathrm{pmol} / \mathrm{l}$ ) and did not change in the norepinephrine group. Low-dose vasopressin infusion increased vasopressin levels to $73.6 \mathrm{pmol} / \mathrm{l}$ (median) at $6 \mathrm{~h}$ and to $98.0 \mathrm{pmol} / \mathrm{l}$ at $24 \mathrm{~h} \mathrm{[10].}$

Overall, there was no significant difference between vasopressin and norepinephrine-treated groups in 28day mortality ( 35.4 vs. $39.3 \%$, respectively, $\mathrm{p}=0.26$ ), in 90 -day mortality ( 43.9 vs. $49.6 \%$, respectively, $\mathrm{p}=0.11$ ) or in organ dysfunction rates.

Vasopressin may have decreased mortality in patients who had less severe septic shock in the VASST. There were trends suggesting an association of vasopressin infusion with decreased 28-day (and 90-day) mortality in less severe septic shock. This finding of possible benefit of vasopressin compared to norepinephrine infusion in less severe shock was robust in that the result was consistent when several definitions of less severe shock were assessed. Vasopressin infusion was associated with decreased mortality rate in less severe septic shock defined by norepinephrine infusion (mortality: vasopressin $26.5 \%$ vs. norepinephrine $35.7 \%, \mathrm{p}=0.05$ ), lowest lactate quartile ( $\leq 1.4 \mathrm{mmol} / \mathrm{l} ; 18.9$ vs. $33.8 \% ; \mathrm{p}=0.03)$ and by use of one vasopressor at baseline (31.3 vs. $39.9 \%$; $p=0.04$ ).

In distinct contrast, there were no differences in mortality in more severe septic shock between vasopressin and norepinephrine. The test for the interaction of treatment group by severity of shock subgroup was not significant $(\mathrm{p}=0.10)$.

The potential benefits of vasopressin (compared to norepinephrine) in patients who had less severe septic shock were somewhat delayed. Kaplan-Meier survival curves show that the vasopressin-treated patients separated from the norepinephrine-treated patients at about day 10 (fig. 4). This delayed separation of the Kaplan-Meier curves could be due to effects of vasopressin on inflammation and immunity, delayed benefit of improved shock, or delayed benefits of the decreased dose of norepinephrine.

There are well-described side effects of infusion of vasopressin as well as norepinephrine in septic shock. In the 
Fig. 4. Kaplan-Meier 90-day survival curve of patients who had less severe septic shock in VASST comparing vasopressininfused to norepinephrine-infused patients. Ninety-day Kaplan-Meier survival curves in patients who had less severe septic shock in the VASST ( $\mathrm{p}=0.05$ at day 28 and $\mathrm{p}=0.03$ at day 90). The Solid black line is the vasopressin-treated group, the dotted line is the norepinephrine-treated group, and the vertical line marks day 28 . $\mathrm{p}$ values were calculated using the log rank statistic [10].

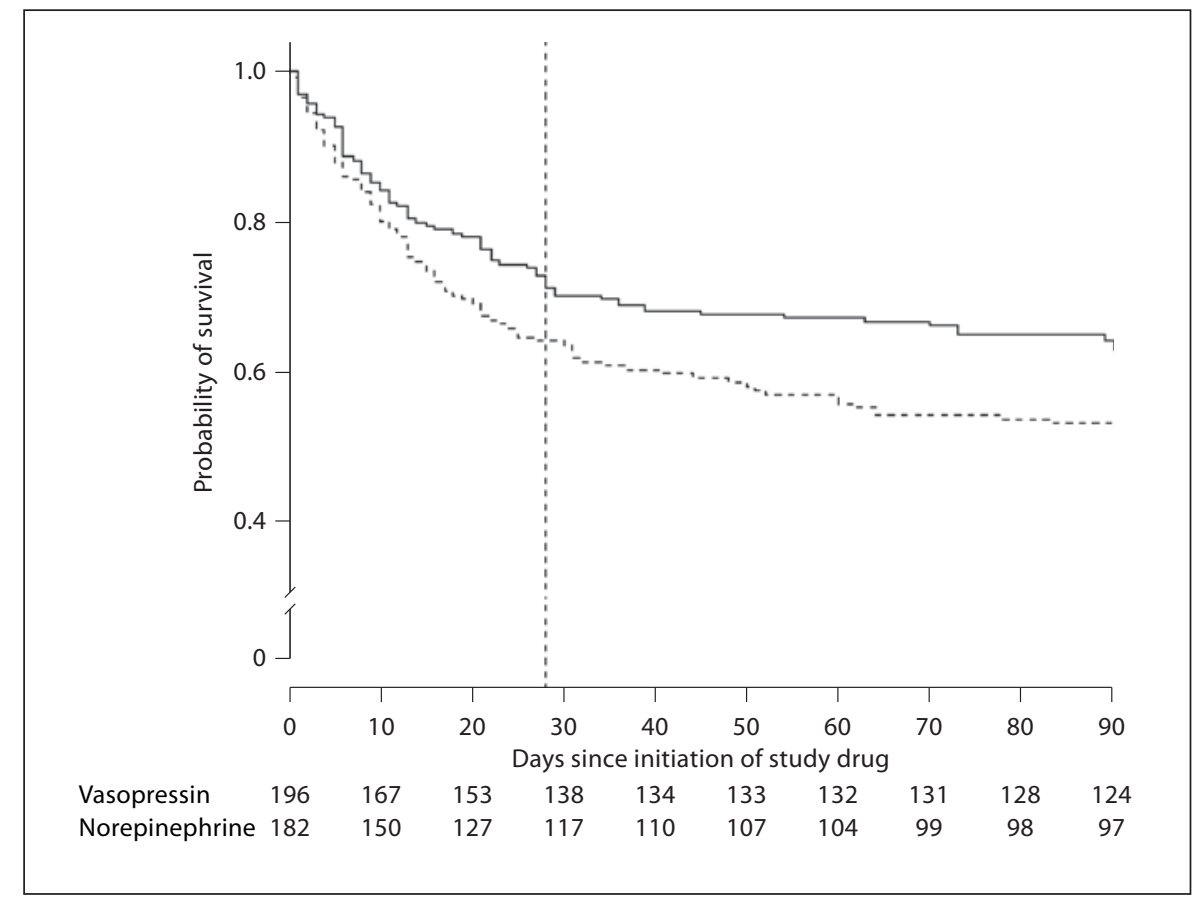

VASST, the rates of serious adverse events were similar in the vasopressin and norepinephrine groups (10.3 vs. $10.5 \%)$. Vasopressin infusion was reported to increase risk of cardiac arrest [1]; in the VASST there were more cardiac arrests in the norepinephrine than in the vasopressin group ( 2.1 vs. $0.8 \%, p=0.14$ ). Other reported adverse effects of vasopressin and norepinephrine are decreased cardiac output $[1,6,7,93]$, mesenteric ischemia $[96,103]$, hyponatremia (vasopressin), skin necrosis [104] and digital ischemia [105]. In the VASST, there was a trend to more digital ischemia in the vasopressin versus norepinephrine group (2.0 vs. $0.5 \%, \mathrm{p}=0.11$ ).

The VASST was the first randomized controlled trial of vasopressin versus norepinephrine that was powered for mortality. Strengths of the VASST include multicenter design, large sample size, blinding, use of lowdose vasopressin, blinded evaluation of serious adverse events, clear inclusion and exclusion criteria, and assessment of pharmacokinetics of vasopressin infusion. Limitations of the VASST are that the vasopressin infusion rate was predetermined, plasma vasopressin levels were not used to guide dose or duration of infusion, the VASST evaluated low-dose vasopressin as a 'catecholamine-sparing drug' and, finally, the mean time from meeting inclusion criteria to study drug infusion was $12 \mathrm{~h}$. Rivers et al. [106] identified benefits of early goaldirected therapy when applied in the first $6 \mathrm{~h}$ after ar- rival in the emergency department with septic shock. There was numerically lower mortality with vasopressin (33.2\% vs. norepinephrine $40.5 \%, \mathrm{p}=0.12$ ) in patients treated within $12 \mathrm{~h}$.

\section{Interactions of Vasopressin Infusion and Corticosteroid Treatment in Septic Shock}

There have been no large studies of the interaction of vasopressin and corticosteroids until the VASST. Many of the patients in the VASST were treated with corticosteroids because they had septic shock. Therefore, we evaluated the interaction of vasopressin infusion, corticosteroid treatment and mortality of septic shock in the VASST [107]. Low-dose vasopressin infusion plus corticosteroids significantly decreased 28-day mortality compared to corticosteroids plus norepinephrine (35.9 vs. $44.7 \%$, respectively, $\mathrm{p}=0.03 ; \mathrm{p}=0.008$ interaction statistic). In patients who were corticosteroid treated, the vasopressin group may have had less organ dysfunction [trend to increased days alive and free of shock $(\mathrm{p}=$ $0.09)$, ventilation $(\mathrm{p}=0.03)$, renal failure $(\mathrm{p}=0.07)$ and to any organ failure $(\mathrm{p}=0.02)]$. In contrast, if patients were not corticosteroid treated, vasopressin may have increased mortality compared to norepinephrine (33.7 vs. $21.3 \%$, respectively, $p=0.06$ ). In patients who re- 
Table 2. Subgroups in the randomized controlled trial of vasopressin versus norepinephrine in septic shock (VASST)

\begin{tabular}{|c|c|c|c|c|c|c|}
\hline & \multicolumn{2}{|c|}{ Less severe shock } & \multirow[t]{2}{*}{$\mathrm{p}$ value } & \multicolumn{2}{|c|}{ more severe shock } & \multirow[t]{2}{*}{$\mathrm{p}$ value } \\
\hline & AVP & $\mathrm{NE}$ & & AVP & $\mathrm{NE}$ & \\
\hline No corticosteroids & $15 / 65(23.1)$ & 9/56 (16.1) & 0.46 & $19 / 36(52.8)$ & $10 / 33(30.3)$ & 0.10 \\
\hline Corticosteroids & $37 / 131(28.2)$ & $56 / 126(44.4)$ & 0.01 & $69 / 164(42.1)$ & $75 / 167(44.9)$ & 0.68 \\
\hline
\end{tabular}

Figures in parentheses are \% mortality. p value is calculated by the $\chi^{2}$ of AVP vs. norepinephrine (NE) in each pair of rows.

ceived vasopressin infusion, corticosteroids increased plasma vasopressin levels significantly by $33 \%$ at $6 \mathrm{~h}$ $(\mathrm{p}=0.001)$ to $67 \%$ at $24 \mathrm{~h}(\mathrm{p}=0.032)$ versus patients who did not receive corticosteroids. Torgersen et al. [95] also found that corticosteroid treatment increased plasma levels of vasopressin.

Some have asked whether there is an inconsistency of the results of the VASST for use of vasopressin versus norepinephrine in less severe and more severe shock subgroups compared to the interaction of vasopressin and corticosteroids. The overlap of severity of shock and use of corticosteroids in the VASST is shown in table 2. There was a significant interaction in the less severe shock subgroup $(\mathrm{p}=0.03)$ and a trend to a significant interaction in the more severe shock subgroup $(\mathrm{p}=0.06)$. Therefore, there is no marked inconsistency between these two subgroup results. Post-hoc analyses must be interpreted cautiously, especially when subgroups have a small sample size.

Plasma vasopressin levels tended to be higher in both less and more severe shock patients who were also treated with corticosteroids: less severe shock, median at $6 \mathrm{~h}: 56.0$ vs. $79.5 \mathrm{pmol} / \mathrm{l}$ (no corticosteroids vs. corticosteroids, $\mathrm{p}=$ $0.10)$, at $24 \mathrm{~h}: 45.5$ vs. $95.9 \mathrm{pmol} / \mathrm{l}(\mathrm{p}=0.11)$; more severe shock, median at 6 h: 37.2 vs. $75.7 \mathrm{pmol} / \mathrm{l}(\mathrm{p}=0.04)$, at 24 h: 72.6 vs. $100.3 \mathrm{pmol} / \mathrm{l}(\mathrm{p}=0.31)$.

The effects of corticosteroids on vasopressin levels and efficacy are consistent with studies showing that corticosteroids increase vasopressin mRNA [108] and restore responsiveness to vasopressin [109].

The effects of vasopressin on the corticosteroid axis are clearer [110-112]. When vasopressin binds to AVR1b (V3) it increases corticotroph responsiveness to CRF, thus increasing ACTH [110-112] even in conditions of stress when corticosteroid levels are increased [110-112]. Vasopressin-induced increase of ACTH (unlike effects of $\mathrm{CRF}$ on $\mathrm{ACTH}$ ) is resistant to corticosteroid-negative feedback because binding to AVR1b is coupled to phos- pholipase $\mathrm{C}$ and is not regulated by corticosteroid levels [112]. Vasopressin infusion did not change serum ACTH or cortisol levels in a cohort of septic shock [88, 90].

Bauer et al. [113] also reported an interaction of vasopressin and corticosteroids in a nonrandomized study of patients with septic shock. Patients who received corticosteroids and vasopressin had lower mortality (compared to patients who did not receive corticosteroids with vasopressin; 47.6 vs. $80.9 \%, p=0.02$ ). A randomized, blinded, placebo-controlled trial of vasopressin plus either corticosteroids or placebo in cardiac arrest found a beneficial interaction of vasopressin and corticosteroids [114]. Patients who received vasopressin plus corticosteroids had more frequent return of spontaneous circulation (81 vs. $52 \%, \mathrm{p}=0.003)$ and higher survival (19 vs. $4 \%, \mathrm{p}=0.02)$ than patients who received vasopressin plus placebo.

It is not known how vasopressin plus corticosteroids (vs. norepinephrine plus corticosteroids) could have altered mortality rates. Potential mechanisms could be that corticosteroid-increased vasopressin levels enhanced responsiveness to vasopressin [106], or the combination of vasopressin and corticosteroids beneficially altered inflammation and immunity.

\section{Conclusions}

Vasopressin levels are inappropriately low in septic shock. Vasopressin stimulates AVPR1a, AVPR1b, AVPR2 and purinergic receptors. The VASST found no overall difference in mortality; however, vasopressin may have decreased mortality in patients who had less severe septic shock. There is an interaction of the vasopressin and corticosteroid axes. Low-dose vasopressin infusion plus corticosteroid treatment decreased mortality compared to corticosteroids plus norepinephrine in the VASST. Vasopressin plus corticosteroids could have altered immunity beneficially in septic shock. Vasopressin has many effects 
on immune function such as altering cytokines, neuroimmunity, prostaglandins, humoral immunity and immune cells. Yet little research has focused on immune effects of vasopressin in septic shock.

\section{Acknowledgments}

The VASST was supported by the Canadian Institutes of Health Research, grant No. MCT 44152, registration ISRCTN94845869 and the Heart and Stroke Foundation of British Columbia and Yukon.

\section{Disclosure Statement}

Dr. Russell and Dr. Walley report holding stock in Sirius Genomics Inc., which has submitted patents owned by the University of British Columbia and licensed to Sirius Genomics, that are related to the genetics of vasopressin and protein $\mathrm{C}$. The University of British Columbia has also submitted a patent related to the use of vasopressin in septic shock. Dr. Russell and Dr. Walley report being an inventor on these patents. Dr. Russell reports receiving consulting fees from Ferring, which manufactures vasopressin, and from Sirius Genomics Inc. Dr. Russell reports receiving grant support from Sirius Genomics, Novartis, Ferring, and Eli Lilly. Dr. Russell has received speaking honoraria from Pfizer and Eli Lilly. Dr. Walley reports receiving grant support from Sirius Genomics Inc.

\section{References}

1 Holmes CL, Walley KR, Chittock DR, Lehman T, Russell JA: The effects of vasopressin on hemodynamics and renal function in severe septic shock: a case series. Intensive Care Med 2001;27:1416-1421.

$\checkmark 2$ Kakiya S, Arima H, Yokoi H, Murase T, Yambe Y, Oiso Y: Effects of acute hypotensive stimuli on arginine vasopressin gene transcription in the rat hypothalamus. Am J Physiol Endocrinol Metab 2000;279:E886E892.

3 Itoi K, Jiang YQ, Iwasaki Y, Watson SJ: Regulatory mechanisms of corticotropin-releasing hormone and vasopressin gene expression in the hypothalamus. J Neuroendocrinol 2004;16:348-355.

-4 Oliveira-Pelegrin GR, Ravanelli MI, Branco LG, Rocha MJ: Thermoregulation and vasopressin secretion during polymicrobial sepsis. Neuroimmunomodulation 2009;16:4553.

5 Russell JA: Vasopressin in septic shock. Crit Care Med 2007;35(suppl):S609-S615.

6 Landry DW, Levin HR, Gallant EM, et al: Vasopressin deficiency contributes to the vasodilation of septic shock. Circulation 1997; 95:1122-1125.

7 Landry DW, Levin HR, Gallant EM, et al: Vasopressin pressor hypersensitivity in vasodilatory septic shock. Crit Care Med 1997; 25:1279-1282.

$\checkmark 8$ Russell JA: Vasopressin in vasodilatory and septic shock. Curr Opin Crit Care 2007;13: 383-391.

-9 Lin IY, Ma HP, Lin AC, Chong CF, Lin CM, Wang TL: Low plasma vasopressin/norepinephrine ratio predicts septic shock. Am J Emerg Med 2005;23:718-724.

10 Russell JA, Walley KR, Singer J, et al: Vasopressin versus norepinephrine infusion in patients with septic shock. N Engl J Med 2008;358:877-887.
11 Carnio EC, Moreto V, Giusti-Paiva A, Antunes-Rodrigues J: Neuro-immune-endocrine mechanisms during septic shock: role for nitric oxide in vasopressin and oxytocin release. Endocr Metab Immune Disord Drug Targets 2006;6:137-142.

12 Correa PB, Pancoto JA, de Oliveira-Pelegrin GR, Carnio EC, Rocha MJ: Participation of iNOS-derived NO in hypothalamic activation and vasopressin release during polymicrobial sepsis. J Neuroimmunol 2007;183: $17-25$.

13 Moreto V, Stabile AM, Antunes-Rodrigues J, Carnio EC: Role of heme-oxygenase pathway on vasopressin deficiency during endotoxemic shock-like conditions. Shock 2006;26: 472-476.

14 Pancoto JA, Correa PB, Oliveira-Pelegrin GR, Rocha MJ: Autonomic dysfunction in experimental sepsis induced by cecal ligation and puncture. Auton Neurosci 2008; 138:57-63.

-15 Bruhn FH, Correa PB, Oliveira-Pelegrin GR, Rocha MJ: Blocking systemic nitric oxide production alters neuronal activation in brain structures involved in cardiovascular regulation during polymicrobial sepsis. Neurosci Lett 2009;453:141-146.

16 Batista MB, Bravin AC, Lopes LM, et al: Pressor response to fluid resuscitation in endotoxic shock: involvement of vasopressin. Crit Care Med 2009;37:2968-2972.

17 Giusti-Paiva A, Martinez MR, Bispo-da-Silva LB, Salgado MC, Elias LL, Antunes-Rodrigues J: Vasopressin mediates the pressor effect of hypertonic saline solution in endotoxic shock. Shock 2007;27:416-421.

18 Gomes DA, Song Z, Stevens W, Sladek CD: Sustained stimulation of vasopressin and oxytocin release by ATP and phenylephrine requires recruitment of desensitization-resistant P2X purinergic receptors. Am J Physiol Regul Integr Comp Physiol 2009; 297:R940-R949.
19 Morgenthaler NG, Muller B, Struck J, Bergmann A, Redl H, Christ-Crain M: Copeptin, a stable peptide of the arginine vasopressin precursor, is elevated in hemorrhagic and septic shock. Shock 2007;28:219-226.

20 Muller B, Morgenthaler N, Stolz D, et al: Circulating levels of copeptin, a novel biomarker, in lower respiratory tract infections. Eur J Clin Invest 2007;37:145-152.

21 Lodha R, Vivekanandhan S, Sarthi M, Kabra SK: Serial circulating vasopressin levels in children with septic shock. Pediatr Crit Care Med 2006;7:220-224.

22 Thibonnier M, Auzan C, Madhun Z, Wilkins P, Berti-Mattera L, Clauser E: Molecular cloning, sequencing, and functional expression of a cDNA encoding the human Vla vasopressin receptor. J Biol Chem 1994;269: 3304-3310.

23 Thibonnier M, Graves MK, Wagner MS, et al: Study of V(1)-vascular vasopressin receptor gene microsatellite polymorphisms in human essential hypertension. J Mol Cell Cardiol 2000;32:557-564.

24 Berrada K, Plesnicher CL, Luo X, Thibonnier M: Dynamic interaction of human vasopressin/oxytocin receptor subtypes with $G$ protein-coupled receptor kinases and protein kinase $\mathrm{C}$ after agonist stimulation. J Biol Chem 2000;275:27229-27237.

$\checkmark 25$ Kim SJ, Young LJ, Gonen D, et al: Transmission disequilibrium testing of arginine vasopressin receptor 1A (AVPR1A) polymorphisms in autism. Mol Psychiatry 2002;7: 503-507.

-26 Knafo A, Israel S, Darvasi A, et al: Individual differences in allocation of funds in the dictator game associated with length of the arginine vasopressin la receptor RS3 promoter region and correlation between RS3 length and hippocampal mRNA. Genes Brain Behav 2008;7:266-275. 
-27 Antoni FA, Holmes MC, Makara GB, Karteszi M, Laszlo FA: Evidence that the effects of arginine-8-vasopressin (AVP) on pituitary corticotropin $(\mathrm{ACTH})$ release are mediated by a novel type of receptor. Peptides 1984;5:519-522.

28 Hernando F, Schoots O, Lolait SJ, Burbach JP: Immunohistochemical localization of the vasopressin $\mathrm{V} 1 \mathrm{~b}$ receptor in the rat brain and pituitary gland: anatomical support for its involvement in the central effects of vasopressin. Endocrinology 2001;142:1659-1668.

-29 Lolait SJ, Stewart LQ, Jessop DS, Young WS, 3rd, O'Carroll AM: The hypothalamic-pituitary-adrenal axis response to stress in mice lacking functional vasopressin V1b receptors. Endocrinology 2007;148:849-856.

30 Martin K, Borgel D, Lerolle N, et al: Decreased ADAMTS-13 (A disintegrin-like and metalloprotease with thrombospondin type 1 repeats) is associated with a poor prognosis in sepsis-induced organ failure. Crit Care Med 2007;35:2375-2382.

- 31 Ono T, Mimuro J, Madoiwa S, et al: Severe secondary deficiency of von Willebrand factor-cleaving protease (ADAMTS13) in patients with sepsis-induced disseminated intravascular coagulation: its correlation with development of renal failure. Blood 2006; 107:528-534.

- 32 Schmidt C, Hocherl K, Kurt B, Bucher M: Role of nuclear factor- $\mathrm{\kappa B}$-dependent induction of cytokines in the regulation of vasopressin V1A-receptors during cecal ligation and puncture-induced circulatory failure. Crit Care Med 2008;36:2363-2372.

33 Roth BL, Spitzer JA: Altered hepatic vasopressin and alpha 1-adrenergic receptors after chronic endotoxin infusion. Am J Physiol 1987;252:E699-E702.

-34 Bucher M, Hobbhahn J, Taeger K, Kurtz A: Cytokine-mediated downregulation of vasopressin $\mathrm{V}(1 \mathrm{~A})$ receptors during acute endotoxemia in rats. Am J Physiol Regul Integr Comp Physiol 2002;282:R979-R984.

- 35 Grinevich V, Knepper MA, Verbalis J, Reyes I, Aguilera G: Acute endotoxemia in rats induces down-regulation of V2 vasopressin receptors and aquaporin-2 content in the kidney medulla. Kidney Int 2004;65:54-62.

36 Qahwash IM, Cassar CA, Radcliff RP, Smith GW: Bacterial lipopolysaccharide-induced coordinate downregulation of arginine vasopressin receptor $\mathrm{V} 3$ and corticotropin-releasing factor receptor 1 messenger ribonucleic acids in the anterior pituitary of endotoxemic steers. Endocrine 2002;18:13-20.

- 37 Barrett LK, Orie NN, Taylor V, Stidwill RP, Clapp LH, Singer M: Differential effects of vasopressin and norepinephrine on vascular reactivity in a long-term rodent model of sepsis. Crit Care Med 2007;35:2337-2343.

-38 Yang G, Liu L, Xu J, Li T: Effect of arginine vasopressin on vascular reactivity and calcium sensitivity after hemorrhagic shock in rats and its relationship to Rho-kinase. J Trauma 2006;61:1336-1342.
9 Yang GM, Li T, Xu J, Ming J, Liu LM: Effect of arginine vasopressin on vascular reactivity and calcium sensitivity of vascular smooth muscle and its relationship to protein kinase $\mathrm{C}$ following hemorrhagic shock in rats. Zhongguo Wei Zhong Bing Ji Jiu Yi Xue 2008;20:139-143.

40 Kawano T, Tanaka K, Nazari H, Oshita S, Takahashi A, Nakaya Y: The effects of extracellular $\mathrm{pH}$ on vasopressin inhibition of ATP-sensitive $\mathrm{K}+$ channels in vascular smooth muscle cells. Anesth Analg 2007; 105:1714-1719, table of contents.

41 Tiniakov R, Scrogin KE: The spleen is required for 5-HT1A receptor agonist-mediated increases in mean circulatory filling pressure during hemorrhagic shock in the rat. Am J Physiol Regul Integr Comp Physiol 2009;296:R1392-R1401.

42 Holmes CL, Patel BM, Russell JA, Walley KR: Physiology of vasopressin relevant to management of septic shock. Chest 2001;120: 989-1002.

43 Simon F, Giudici R, Scheuerle A, et al: Comparison of cardiac, hepatic, and renal effects of arginine vasopressin and noradrenaline during porcine fecal peritonitis: a randomized controlled trial. Crit Care 2009;13:R113.

44 Ryckwaert F, Virsolvy A, Fort A, et al: Terlipressin, a provasopressin drug exhibits direct vasoconstrictor properties: consequences on heart perfusion and performance. Crit Care Med 2009;37:876-881.

45 Muller S, How OJ, Hermansen SE, Stenberg TA, Sager G, Myrmel T: Vasopressin impairs brain, heart and kidney perfusion: an experimental study in pigs after transient myocardial ischemia. Crit Care 2008;12:R20.

46 Indrambarya T, Boyd JH, Wang Y, McConechy M, Walley KR: Low-dose vasopressin infusion results in increased mortality and cardiac dysfunction following ischemia-reperfusion injury in mice. Crit Care 2009; 13:R98.

47 Patel BM, Chittock DR, Russell JA, Walley KR: Beneficial effects of short-term vasopressin infusion during severe septic shock. Anesthesiology 2002;96:576-582.

48 Sawa N, Ubara Y, Katori H, et al: The longterm survival rate of catecholamine-resistant septic shock in Japanese patients who received vasopressin therapy. Clin Nephrol 2009;72:129-136.

49 Bragadottir G, Redfors B, Nygren A, Sellgren J, Ricksten SE: Low-dose vasopressin increases glomerular filtration rate, but impairs renal oxygenation in post-cardiac surgery patients. Acta Anaesthesiol Scand 2009; 53:1052-1059.

50 Gordon AC, Russell JA, Walley KR, et al: The effects of vasopressin on acute kidney injury in septic shock. Intensive Care Med 2009; 36:83-91.
51 Hocherl K, Schmidt C, Kurt B, Bucher M: Inhibition of NF- $\kappa \mathrm{B}$ ameliorates sepsis-induced downregulation of aquaporin-2/V2 receptor expression and acute renal failure in vivo. Am J Physiol Renal Physiol;298:F196F204.

-52 Versteilen AM, Heemskerk AE, Groeneveld $A B$, van Wijhe $M$, van Lambalgen AA, Tangelder GJ: Mechanisms of the urinary concentration defect and effect of desmopressin during endotoxemia in rats. Shock 2008;29: 217-222.

53 Chagnon F, Vaidya VS, Plante GE, et al: Modulation of aquaporin-2/vasopressin 2 receptor kidney expression and tubular injury after endotoxin (lipopolysaccharide) challenge. Crit Care Med 2008;36:3054-3061.

54 Hiltebrand LB, Krejci V, Jakob SM, Takala J, Sigurdsson GH: Effects of vasopressin on microcirculatory blood flow in the gastrointestinal tract in anesthetized pigs in septic shock. Anesthesiology 2007;106:1156-1167.

55 Krejci V, Hiltebrand LB, Jakob SM, Takala J, Sigurdsson GH: Vasopressin in septic shock: effects on pancreatic, renal, and hepatic blood flow. Crit Care 2007;11:R129.

56 Di Giantomasso D, Morimatsu H, Bellomo $\mathrm{R}$, May CN: Effect of low-dose vasopressin infusion on vital organ blood flow in the conscious normal and septic sheep. Anaesth Intensive Care 2006;34:427-433.

57 Kang CH, Kim WG: The effect of vasopressin on organ blood flow in an endotoxin-induced rabbit shock model. J Invest Surg 2006;19:361-369.

58 Kopel T, Losser MR, Faivre V, Payen D: Systemic and hepatosplanchnic macro- and microcirculatory dose response to arginine vasopressin in endotoxic rabbits. Intensive Care Med 2008;34:1313-1320.

59 Knotzer H, Maier S, Dunser MW, et al: Arginine vasopressin does not alter mucosal tissue oxygen tension and oxygen supply in an acute endotoxemic pig model. Intensive Care Med 2006;32:170-174.

60 Nakajima Y, Baudry N, Duranteau J, Vicaut E: Effects of vasopressin, norepinephrine, and L-arginine on intestinal microcirculation in endotoxemia. Crit Care Med 2006;34: 1752-1757.

61 Meybohm P, Cavus E, Dorges V, et al: Release of protein S100B in haemorrhagic shock: effects of small volume resuscitation combined with arginine vasopressin. Resuscitation 2008;76:449-456.

62 Moresi V, Garcia-Alvarez G, Pristera A, et al: Modulation of caspase activity regulates skeletal muscle regeneration and function in response to vasopressin and tumor necrosis factor. PLoS One 2009;4:e5570.

63 Boyd JH, Kan B, Roberts H, Wang Y, Walley KR: S100A8 and S100A9 mediate endotoxininduced cardiomyocyte dysfunction via the receptor for advanced glycation end products. Circ Res 2008;102:1239-1246. 
64 Jonkam CC, Lange M, Traber DL, et al: Cardiovascular collapse and vascular permeability changes in an ovine model of methicillin-resistant Staphylococcus aureus sepsis. Shock 2009;32:621-625.

-65 Lange M, Hamahata A, Enkhbaatar P, et al: Assessment of vascular permeability in an ovine model of acute lung injury and pneumonia-induced Pseudomonas aeruginosa sepsis. Crit Care Med 2008;36:1284-1289.

66 Rehberg S, Ertmer C, Kohler G, et al: Role of arginine vasopressin and terlipressin as firstline vasopressor agents in fulminant ovine septic shock. Intensive Care Med 2009;35: 1286-1296.

67 Zhao L, Brinton RD: Suppression of proinflammatory cytokines interleukin-1beta and tumor necrosis factor-alpha in astrocytes by a V1 vasopressin receptor agonist: a cAMP response element-binding protein-dependent mechanism. J Neurosci 2004;24:2226-2235.

- 68 Boyd JH, Holmes CL, Wang Y, Roberts H, Walley KR: Vasopressin decreases sepsis-induced pulmonary inflammation through the V2R. Resuscitation 2008;79:325-331.

69 Chassin C, Hornef MW, Bens M, et al: Hormonal control of the renal immune response and antibacterial host defense by arginine vasopressin. J Exp Med 2007;204:2837-2852.

-70 Hagberg L, Hull R, Hull S, McGhee JR, Michalek SM, Svanborg Eden C: Difference in susceptibility to gram-negative urinary tract infection between $\mathrm{C} 3 \mathrm{H} / \mathrm{HeJ}$ and $\mathrm{C} 3 \mathrm{H} / \mathrm{HeN}$ mice. Infect Immun 1984;46:839-844.

-71 Banisadr G, Skrzydelski D, Kitabgi P, Rostene W, Parsadaniantz SM: Highly regionalized distribution of stromal cell-derived factor-1/CXCL12 in adult rat brain: constitutive expression in cholinergic, dopaminergic and vasopressinergic neurons. Eur J Neurosci 2003;18:1593-1606.

-72 Shibasaki T, Hotta M, Sugihara H, Wakabayashi I: Brain vasopressin is invlolved in stress-induced suppression of immune function in the rat. Brain Res 1998;808:84-92.

-73 Koike K, Sakamoto Y, Kiyama H, Masuhara $\mathrm{K}$, Miyake A, Inoue M: Cytokine-induced neutrophil chemoattractant gene expression in the rat hypothalamus by osmotic stimulation. Brain Res Mol Brain Res 1997;52:326329.

-74 Fleisher-Berkovich S, Kagan E, Grossman N, Danon A: Multiple effects of arginine vasopressin on prostaglandin E2 synthesis in fibroblasts. Eur J Pharmacol 2004;485:53-59.

75 Baker C, Richards LJ, Dayan CM, Jessop DS: Corticotropin-releasing hormone immunoreactivity in human $\mathrm{T}$ and $\mathrm{B}$ cells and macrophages: colocalization with arginine vasopressin. J Neuroendocrinol 2003; 15 : 1070-1074.

76 Geenen V, Defresne MP, Robert F, Legros JJ, Franchimont $\mathrm{P}$, Boniver J: The neurohormonal thymic microenvironment: immunocytochemical evidence that thymic nurse cells are neuroendocrine cells. Neuroendocrinology 1988;47:365-368.
77 Jessop DS, Chowdrey HS, Lightman SL, Larsen PJ: Vasopressin is located within lymphocytes in the rat spleen. J Neuroimmunol 1995;56:219-223.

78 Wickramasinghe SN, Valdimarsson H, Williams B: Interaction between a synthetic analogue of vasopressin and human peripheral blood lymphocytes. J Clin Lab Immunol 1982;7:67-70.

79 Chowdrey HS, Lightman SL, Harbuz MS, Larsen PJ, Jessop DS: Contents of corticotropin-releasing hormone and arginine vasopressin immunoreactivity in the spleen and thymus during a chronic inflammatory stress. J Neuroimmunol 1994;53:17-21.

80 Ekman R, Gobom J, Persson R, Mecocci P, Nilsson CL: Arginine vasopressin in the cytoplasm and nuclear fraction of lymphocytes from healthy donors and patients with depression or schizophrenia. Peptides 2001;22: 67-72.

81 Bell J, Adler MW, Greenstein JI, Liu-Chen LY: Identification and characterization of [125I] arginine vasopressin binding sites on human peripheral blood mononuclear cells. Life Sci 1993;52:95-105.

82 Elands J, van Woudenberg A, Resink A, de Kloet ER: Vasopressin receptor capacity of human blood peripheral mononuclear cells is sex dependent. Brain Behav Immun 1990; 4:30-38.

83 Reder AT: Regulation of production of adrenocorticotropin-like proteins in human mononuclear cells. Immunology 1992;77: 436-442.

84 Bell J, Adler MW, Greenstein JI: The effect of arginine vasopressin on the autologous mixed lymphocyte reaction. Int J Immunopharmacol 1992;14:93-103.

$85 \mathrm{Hu}$ SB, Zhao ZS, Yhap C, et al: Vasopressin receptor la-mediated negative regulation of B cell receptor signaling. J Neuroimmunol 2003;135:72-81.

86 Yirmiya R, Shavit Y, Ben-Eliyahu S, et al: Natural killer cell activity in vasopressindeficient rats (Brattleboro strain). Brain Res 1989;479:16-22.

87 Argenziano M, Chen JM, Choudhri AF, et al: Management of vasodilatory shock after cardiac surgery: identification of predisposing factors and use of a novel pressor agent. J Thorac Cardiovasc Surg 1998;116:973-980.

88 Dunser MW, Mayr AJ, Ulmer H, et al: The effects of vasopressin on systemic hemodynamics in catecholamine-resistant septic and postcardiotomy shock: a retrospective analysis. Anesth Analg 2001;93:7-13.

89 Dunser MW, Mayr AJ, Stallinger A, et al: Cardiac performance during vasopressin infusion in postcardiotomy shock. Intensive Care Med 2002;28:746-751.

90 Dunser MW, Mayr AJ, Ulmer H, et al: Arginine vasopressin in advanced vasodilatory shock: a prospective, randomized, controlled study. Circulation 2003;107:23132319.
91 Lauzier F, Levy B, Lamarre P, Lesur O: Vasopressin or norepinephrine in early hyperdynamic septic shock: a randomized clinical trial. Intensive Care Med 2006;32: 1782-1789.

92 Luckner G, Dunser MW, Jochberger S, et al: Arginine vasopressin in 316 patients with advanced vasodilatory shock. Crit Care Med 2005;33:2659-2666.

\$3 Luckner G, Mayr VD, Jochberger S, et al: Comparison of two dose regimens of arginine vasopressin in advanced vasodilatory shock. Crit Care Med 2007;35:2280-2285.

$\$ 4$ Malay MB, Ashton RC, Jr., Landry DW, Townsend RN: Low-dose vasopressin in the treatment of vasodilatory septic shock. J Trauma 1999;47:699-703; discussion 703705.

95 Torgersen C, Dunser MW, Wenzel V, et al: Comparing two different arginine vasopressin doses in advanced vasodilatory shock: a randomized, controlled, open-label trial. Intensive Care Med 2009;36:5765.

96 van Haren FM, Rozendaal FW, van der Hoeven JG: The effect of vasopressin on gastric perfusion in catecholamine-dependent patients in septic shock. Chest 2003; 124:2256-2260.

97 Argenziano M, Chen JM, Cullinane S, et al: Arginine vasopressin in the management of vasodilatory hypotension after cardiac transplantation. J Heart Lung Transplant 1999;18:814-817.

98 Argenziano M, Choudhri AF, Oz MC, Rose EA, Smith CR, Landry DW: A prospective randomized trial of arginine vasopressin in the treatment of vasodilatory shock after left ventricular assist device placement. Circulation 1997;96(9 suppl):II286-II290.

$\checkmark 99$ Morales DL, Gregg D, Helman DN, et al: Arginine vasopressin in the treatment of 50 patients with postcardiotomy vasodilatory shock. Ann Thorac Surg 2000;69:102-106.

100 Rosenzweig EB, Starc TJ, Chen JM, et al: Intravenous arginine-vasopressin in children with vasodilatory shock after cardiac surgery. Circulation 1999;100(19 suppl):II182II186.

101 Chen JM, Cullinane S, Spanier TB, et al: Vasopressin deficiency and pressor hypersensitivity in hemodynamically unstable organ donors. Circulation 1999;100(19 suppl):I244-II246.

102 Gold J, Cullinane S, Chen J, et al: Vasopressin in the treatment of milrinone-induced hypotension in severe heart failure. Am J Cardiol 2000;85:506-508, A11.

103 Klinzing S, Simon M, Reinhart K, Bredle DL, Meier-Hellmann A: High-dose vasopressin is not superior to norepinephrine in septic shock. Crit Care Med 2003;31:26462650. 
104 Dunser MW, Mayr AJ, Tur A, et al: Ischemic skin lesions as a complication of continuous vasopressin infusion in catecholamine-resistant vasodilatory shock: incidence and risk factors. Crit Care Med 2003;31:1394-1398.

105 Hayes MA, Yau EH, Hinds CJ, Watson JD: Symmetrical peripheral gangrene: association with noradrenaline administration. Intensive Care Med 1992;18:433-436.

106 Rivers E, Nguyen B, Havstad S, et al: Early goal-directed therapy in the treatment of severe sepsis and septic shock. N Engl J Med 2001;345:1368-1377.

107 Russell JA, Walley KR, Gordon AC, et al: Interaction of vasopressin infusion, corticosteroid treatment, and mortality of septic shock. Crit Care Med 2009;37:811-818.
108 Pietranera L, Saravia F, Roig P, Lima A, De Nicola AF: Mineralocorticoid treatment upregulates the hypothalamic vasopressinergic system of spontaneously hypertensive rats. Neuroendocrinology 2004;80:100110.

109 Ertmer C, Bone HG, Morelli A, et al: Methylprednisolone reverses vasopressin hyporesponsiveness in ovine endotoxemia. Shock 2007;27:281-288.

110 Rabadan-Diehl C, Aguilera G: Glucocorticoids increase vasopressin $\mathrm{V} 1 \mathrm{~b}$ receptor coupling to phospholipase C. Endocrinology 1998;139:3220-3226.

11 Tanoue A, Ito S, Honda K, et al: The vasopressin V1b receptor critically regulates hypothalamic-pituitary-adrenal axis activity under both stress and resting conditions. J Clin Invest 2004;113:302-309.
112 Aguilera G, Rabadan-Diehl C: Vasopressinergic regulation of the hypothalamic-pituitary-adrenal axis: implications for stress adaptation. Regul Pept 2000;96:23-29.

113 Bauer SR, Lam SW, Cha SS, Oyen LJ: Effect of corticosteroids on arginine vasopressincontaining vasopressor therapy for septic shock: a case control study. J Crit Care 2008; 23:500-506.

114 Mentzelopoulos SD, Zakynthinos SG, Tzoufi M, et al: Vasopressin, epinephrine, and corticosteroids for in-hospital cardiac arrest. Arch Intern Med 2009;169:15-24.

115 Cagliani R, Fumagalli M, Pozzoli U, Riva S, Cereda M, Comi GP, Pattini L, Bresolin N, Sironi M: A complex selection signature at the human AVPR1B gene. BMC Evol Biol 2009;9:123. 